\title{
Impressões de Maksim Górki sobre Vassíli Sleptsov - Um estudo sobre o Realismo Russo e a importância de dar voz às minorias
}

Odomiro Fonseca

\begin{abstract}
Resumo: No presente trabalho, trazemos a tradução de um artigo do consagrado escritor Maksim Górki sobre o desconhecido Vassili Sleptsov, um escritor próprio do Realismo Russo, que viajou - a pé-pelas estradas e confins de sua pátria a estudar e captar a essência de sua população mais vulnerável: os camponeses. Sleptsov deu voz às canções populares e mostron a miséria do trabalhador russo sem floreios. Mesmo com o reconbecimento de pares como Liév Tolstói, Ivan Turguêniev e Kornei Tchukóvski, sua obra permaneceu esquecida por mais de um século. Hoje há um movimento internacional pelo resgate de suas obras.
\end{abstract}

Palavras-Chave: Literatura Russa; Realismo Russo; Niilismo Russo; Vassili Sleptsov; Tradução.

\begin{abstract}
In the present text, we bring the translation of an article by the renowned writer Maxim Gorky about the unknown Vasily Sleptsov, a writer of Russian Realism, who traveled - by foot - along the roads and limits of his bomeland to study and capture the essence of its most vulnerable population: the peasants. Sleptsov gave voice to the popular songs and showed the misery of the Russian worker without flourishes. Even with the recognition of writers like Leo Tolstoy, Ivan Turgenev and Kornei Tchukovski, his work remained forgotten for more than a century. Today there is an international movement for the rescue of his works.
\end{abstract}

Keywords: Russian Literature; Russian Realism; Russian Nibilism; Vasily Sleptsov; Translation.

\section{Sleptsov, um esquecido representante do Realismo Russo}

Um dos períodos mais movimentados da história da Rússia é o que envolve a regência (1855-1881) do tsar Alexandre II (1818-1881). Marcado por uma expressiva abertura política e por reformas estruturais na sociedade, seu governo também foi palco de acaloradas discussões sobre os destinos do país, que envolviam desde 
os setores mais conservadores da sociedade até os que estavam na vanguarda do pensamento liberal-radical - esses últimos conhecidos como Niilistas, pelo fato de negarem veementemente qualquer associação do futuro da Rússia ao regime autocrático. A literatura, como meio principal de difusão e debates, também passou por importantes transformações nesse período, após a entrada de críticos liberais-radicais no comando editorial da principal revista grossa do período, $\mathrm{O}$ Contemporâneo (Sovreménnik). Os principais nomes eram o de Nikolai Tchernichévski (1828-1889) e Nikolai Dobroliúbov (1836-1861), que passaram a pregar por um realismo que fosse voltado para a participação e educação política das massas.

Dobroliúbov e Tchernichévski acreditavam que a introdução de uma linguagem mais fiel à realidade dos camponeses e dos proletários das grandes cidades, além da abertura de espaço nas revistas para escritores que viessem do seio do povo, ajudaria a despertar os setores letrados da sociedade para a necessidade de mudanças, e consequentemente, a multiplicação desse tipo tão esperado: o novo homem. Para isso, a literatura teria de desenvolver seu papel social, onde a arte deveria obedecer às regras preestabelecidas de didatismo social. Para esses críticos, a Beleza seria um adereço da atividade literária, não seu fim; o fundamental numa obra de arte seria seu poder de despertar o aprendizado e a reflexão. Seguindo esse modelo de didatismo literário, vários escritores raznotchinests ${ }^{1}$ ganharam evidência na revista de maior circulação do país. Embora fosse de origem nobre, Sleptsov apareceu nesse cenário em que a literatura dava bastante espaço ao naturalismo da vida camponesa e dos casebres pobres das grandes cidades.

Nascido em 31 de julho de 1836, na cidade de Vorônej, sul da Rússia, Vassíli Sleptsov é um escritor quase desconhecido da crítica literária internacional. Para se ter uma noção do desinteresse por sua obra, até meados de 2016, seu único trabalho traduzido para o inglês era o conto "A enfermaria", de 1863, publicado numa coletânea de contos russos de $1987^{2}$. Existiam apenas duas traduções do seu principal trabalho, o romance "Tempos Difíceis", para o finlandês e o polonês; mas no final do ano citado, entusiastas de sua obra, os pesquisadores estadunidenses William C. Brumfield e Michael R. Katz disponibilizaram a primeira tradução para a língua inglesa do romance. Apesar da boa nova, numa visita a um sítio virtual democrático como a Wikipédia, por exemplo, vemos como sua descrição ainda é

1 Aquele que não tem classe social definida, ou seja, escritores de origem não nobre.

2 In the Depths: Nineteenth-century Russian stories. Compilled by Anatoley Shavkuta, Nikolai Tkachenko, Evgueny Lebedev and Alexander Valdman. 293 pages. Raduga Publishers, 1987. 
modesta. Visitar Sleptsov pode parecer um exótico caso de garimpagem literária, se não houvesse pistas e testemunhos respeitáveis sobre sua qualidade artística e importância no contexto social dos anos 1860.

Recentemente, Sleptsov passou a despertar interesse da crítica com a tese de Victoria Thorstensson ("The Dialog with Nihilism in Russian Polemical Novels of the 1860s-1870s"), de 2013; e o longo artigo de William Brumfield ("Sleptsov Redivivus"), de 2014. Ambos os trabalhos mostram que a obra de Sleptsov contém importantes elementos para o entendimento dos questionamentos mais vivazes da instigante década de 1860 - e mais do que isso: apesar do esquecimento, por razões que analisaremos adiante, Sleptsov sempre foi considerado um escritor de respeito por seus pares.

Sua carreira começa em 1860, aos 24 anos de idade, quando Sleptsov encontrava-se sozinho na agitada Moscou, e não tardou a se agrupar aos jovens "radicais" que frequentavam o salão da condessa e escritora Evguênia Tur (18151892). Da amizade com seu filho, Evguêni, surgiu a possibilidade de publicar seu primeiro texto numa importante revista-grossa, O Discurso Russo (Russkaia Riêtch), fundada por Evguênia Tur, ainda em 1860. Já nesse período, Sleptsov estava muito afinado com o padrão estético proposto por Tchernichévski e a ideia de conciliar o discurso intelectual com o popular fascinava-o. Outra importante influência na construção da poiésis de Sleptsov foi a aproximação com o poeta Vladímir Dál (1801-1872), importante pesquisador, literato da vida camponesa russa e membro fundador da Sociedade Geográfica Russa. Dál, que Sleptsov conhecera na faculdade, já era um escritor respeitado e conhecido como um dos grandes nomes da literatura popular russa e que reunia uma grande erudição aliada ao desejo de pesquisar de perto o inesgotável manancial folclórico da vida camponesa. A presença de Dál incitou no jovem escritor o devir de aproximar-se do povo e conhecê-lo por dentro, nas aldeias.

A pedido de Dál, Sleptsov foi admitido na Seção Etnográfica da Sociedade Geográfica Russa, e partiu a pé, em novembro de 1860, pelos povoados da província de Vladímir a fim de recolher ditos, canções e histórias do imaginário popular russo. As anotações e impressões deixaram marcas perenes nos trabalhos literários de Sleptsov. Desde o seu primeiro ensaio literário, "Vladímirka e Kliázma" (Vladimirka i Kliázma), a produção de Sleptsov, ficcional ou jornalística, foi permeada pela presença do estudo etnográfico das populações aldeãs. Em "Vladímirka e Kliázma”, Sleptsov expõe um vasto repertório do vernáculo camponês, mas também denuncia as condições precárias em que eles trabalhavam, num contato rudimentar e agressivo entre o progresso e a tradição. 
No período em que Sleptsov viajou a pé, acompanhou a construção de uma ponte sobre o rio Kliázma, onde a convivência entre os engenheiros franceses e os trabalhadores de origem camponesa russa delineava todo o abismo existente entre os dois mundos que convergiam naquela construção.

Os efeitos da industrialização no campo, a ineficiência, a corrupção na construção da estrada de ferro de Moscou a Níjni-Nóvgorod e as intoleráveis condições em que os trabalhadores russos eram forçados a viver; foram tratadas e abordadas dentro dos termos do que hoje chamamos de "reportagem investigativa", mas que naquele tempo atendia ao termo oblitchênie (crítica). Em resumo, não seria injusto incluir Vladímirka i Kliažma no mesmo patamar literário dos relatos de viajantes na literatura russa, em que figuram: Viagem de Petersburgo a Moscou (Puteschéstvie iz Petersburga $v$ Moskvu), de Radíschev; e a Ilha Sakhalina (Ostróv Sakbalin), de Tchékhov (BRUMFIELD, 2014; 362).

Para Górki, o trabalho de Sleptsov era inovador no sentido de atender ao chamado de Tchernitchévski para a literatura realista; de dar voz às populações esquecidas dos vilarejos mais remotos. Em 1861, após retornar a Petersburgo de sua peregrinação etnográfica, a atividade criativa de Sleptsov se intensificou. Abonado pelos elogios dos liberais, viajou em novembro de 1861 para a vila de Ostáchkov, na província de Tver, a fim de recolher material para mais um compêndio de realismo etnográfico. "Cartas sobre Ostáchkov" (Pismá ob Ostachkóve) é publicado em O Contemporâneo em 1862, seguindo os mesmos moldes denunciativos (corrupção burocrática e social) de "Vladímirka e Kliázma". As nove cartas narram a desilusão com a histórica cidade que prometia ser o eldorado da industrialização têxtil russa, comandada pela tradicional família Sávin que regia a política local desde o início do século XIX. Ostáchkov recebeu inúmeros trabalhadores que buscavam vagas nas indústrias de curtição de couro ou de telhas. Porém, a evolução do processo industrial não se firmou e durante toda a segunda metade do século XIX, a cidade de Ostáchkov passou por um período de êxodo e decadência.

Suas observações sobre a implantação de uma cultura liberal em Ostáchkov por parte da família Sávin foram as mais pessimistas possíveis; profundamente influenciado pela leitura de Marx e Engels, a desilusão com as condições de trabalho lembram aquelas expostas em "A Situação da Classe Trabalhadora em 1840"3. Sleptsov desacreditou num futuro que passasse pela morosidade das reformas, para

3 Rogatchevskii, op. cit., 50. 
o escritor era necessário que o povo iletrado e a intelectualidade russa tomassem o mesmo caminho, de modo direto, revolucionário. Sua aproximação com as ideias do corpo editorial da revista $\mathrm{O}$ Contemporâneo (que já havia publicado dois artigos em 1861 sobre os trabalhos de Marx e Engels) renderam-lhe um espaço contínuo na revista grossa de maior alcance entre os liberais da Rússia. Foram publicados no suplemento Notas de Petersburgo (Petersburgskie Zamiétki), que acompanhava O Contemporâneo, entre 1863 e 1864, os contos "Pitómka" (Pitómka), "Acampamento Noturno" (Notchleg) e "Porcos" (Svini), além de resumos, críticas e crônicas jornalísticas. Fora de "O Contemporâneo", no mesmo período, Sleptsov publicou a história "O Coral” (Spiêvkea) na revista Anais da Pátria (Otetchéstvennie Zapiskę), e algumas notas críticas na Abelha do Norte (Siévernaia Ptchelâ) - revista que estava sob supervisão editorial do escritor Nikolai Leskóv (1831-1895), com quem ainda mantinha uma relação oscilante de amizade.

Desses trabalhos, "Pitómka" foi o que alcançou maior êxito e comoção entre o público. Escrito num tom triste e sentimental, arrancou elogios afetuosos de Tolstói e Turguêniev, entre outros. Os demais trabalhos se caracterizavam por um tom humorístico, que se transformou numa marca registrada de Sleptsov; humor escrito numa linguagem esópica que chegou a enganar os críticos soviéticos mais de meio século após as suas publicações. Era comum que analisassem o tom jocoso de suas observações como desrespeito e deboche aos camponeses. No seu artigo de apresentação às "Obras Completas de Sleptsov", publicado em 1967, o poeta e crítico Kornêi Tchukóvski relata algumas acusações sofridas por Sleptsov:

A maioria dos críticos estava inclinada à ideia de que Sleptsov posicionara-se à margem da heroica luta pela emancipação das massas. Alguns até mesmo afirmavam que ele adotara uma postura cínica em relação à libertação dos servos, que ele zombava do povo russo. 'Ele - escreveu o jornal liberal Gazeta Russa (Russkie Vedomósti) - não se angustia nem sente raiva; ele ri friamente, como se constatando que o fenômeno social é incapaz de lhe causar qualquer sentimento, exceto o desprezo e a noção do ridículo.(... ${ }^{4}$

O próprio Tchukóvski confessa que por muitos anos aceitou a opinião geral de alguns críticos soviéticos sobre Sleptsov, até se dar conta de que o escritor "niilista" utilizava-se da linguagem esópica em sua narrativa - tanto ficcional,

4 Tchukóvski, K. I., Litieratúrnaia Sudbá Vassilia Sleptsova. Litieratúrnoe Nasliêdstvo, T. 71, 1963. P. 9. Traduzido do russo pelo autor do artigo. 
quanto jornalística. O discurso esópico (ezopóvskaia riêtch) era uma característica recorrente dos escritores da Época dos Romances Polêmicos, que visava a driblar a rígida censura, elaborando uma história principal de pano de fundo, mas que escondia o tom denunciatório da narrativa. Entre seus pares do início da década de 1860, a linguagem criptografada era compreendida, mas para os críticos das décadas vindouras, sua ironia soou como deboche.

Essa linguagem é bem conhecida pelos escritores dos anos 1860. Mas as gerações subsequentes esqueceram-na e perderam a chave que abria a mensagem criptografada, por não atentarem aos artigos jornalísticos de Sleptsov, publicados na revista $O$ Contemporâneo, e outros periódicos da época. Não sabiam que, além do significado explícito, esses artigos possuíam um segredo, um significado secreto, que os pesquisadores atribuíram à categoria de rascunhos, sem conceder-lhes valor literário ou político. ${ }^{5}$

No início da década de 1860, Sleptsov possuía cadeira cativa como colunista da revista O Contemporâneo, escrevendo na coluna Notas Petersburguesas (Peterburgskie Zamiétki), onde combatia, com o magistral auxílio da linguagem esópica, a burocracia governamental, a corrupção das instituições e a falta de perspectivas no campo e na cidade após a emancipação desordenada dos servos. Sua antipatia pelo governo e a defesa dos artistas e da população marginalizada renderam-lhe o qualificado epíteto de "advogado do povo". Nessa primeira metade da década de 1860, podemos afirmar que Sleptsov gozava de enorme prestígio e popularidade entre a intelectualidade russa.

Porém, quando morre, em 1878, o obituário em homenagem a Sleptsov já o classifica como um escritor "quase desconhecido". ${ }^{6}$ Dez anos após sua morte, a revista Espigas (Kolóssia) escreve um discreto artigo o chamando de "escritor desconhecido". Vinte e cinco anos depois, na revista Novo Tempo (Novoe V rêmia), 1903, uma curta nota também já o descrevia como "escritor desconhecido".

O nome de Vassíli Sleptsov entra no século XX esquecido, imperceptível ao mercado editorial. Quando, em 1923, a pedido de Górki, foi publicada uma edição de "Obras Completas" em tomo único, a mesma saiu com diversos erros grotescos, onde o ensaio literário "Vladímirka e Kliázma” foi publicado de modo desajeitado, com o início da história na parte final, entre outros exemplos de desleixo.

5 Tchukóvski, idem. Traduzido do russo pelo autor do artigo.

6 Idem, 11. 
Hoje, com a recém-publicação do romance “Tempos Difíceis" em língua inglesa, acredita-se que um novo interesse do público recaia sobre seu trabalho - tão importante para entendermos a linguagem e a sociedade russa da época do Realismo Russo. A obra de Sleptsov aguarda sua primeira tradução para a língua portuguesa, em que o tradutor deverá ter ciência do empenho que consistirá se envolver com expressões típicas do campesinato russo e com um humor sarcástico sobre as relações sociais existentes. Como aperitivo para as futuras traduções, deixamos esse artigo de Górki, escrito em 1922, mas só publicado em março de 1932, na coletânea Herança Literária (Literatúrnoe Naslédstvo), em que ele revela todo o potencial da obra de Sleptsov e os desafios propostos por sua linguagem.

\section{Sobre Vassíli Sleptsov (por Maksim Górki) ${ }^{7}$}

O grandioso e original talento de Sleptsov pode, em certa medida, ser aparentado à maravilhosa maestria de A. P. Tchékhov; embora Sleptsov não carregue a mesma lírica pensativa e triste, a mesma contemplação diante da natureza e dos temas suaves, tampouco a mesma precisão no trabalho com a linguagem que possui Antón Tchékhov. Porém, ambos possuem em comum a mesma agudeza nas observações, a independência intelectual e atitudes céticas similares diante da realidade russa. Essas características aproximam, em termos gerais, esses escritores tão distantes entre si.

Os ensaios de Sleptsov apareceram naquele período caracterizado na Literatura Russa pelo surgimento da alardeada temática do "nobre arrependido", que soava como uma sincera confissão dos filhos diante dos pecados de seus ancestrais; uma confissão multifacetada, nem sempre sincera e apropriada à duras penas, pois aqueles que foram chamados "filhos dos pecadores" ("Os pais comeram uvas verdes, e os dentes dos filhos se embotaram”, Jeremias 31;29) foram vítimas de uma inevitabilidade histórica, obrigatória e necessária ao desenvolvimento cultural de todos os povos, que se entregaram a uma teimosa luta contra os fósseis do passado, de corpo e alma, com toda a existência e o sentimento. Então, deu-se um segundo ato neste estranho drama romântico que envolve a Literatura Russa e sua relação com a sociedade: de um lado, aparece a figura do apaixonado herói intelliguent, do outro, o povo insensível - as pessoas de verdade, que constituíam a imensa maioria da população. Esses, os camponeses e os outros trabalhadores,

7 Tradução do original russo disponibilizado no endereço eletrônico: http://gorkiy. lit-info.ru/gorkiy/articles/article-365.htm 
praticamente não existiam ou eram mencionados pela Literatura. Logo então, o povo passou a aparecer em suas páginas em tom apaixonado e elevado, numa tentativa de justificar, antes de tudo, um conhecimento positivo de sua essência e psiquê; exagerando-a muitas vezes, mas normalmente tentando despertar uma atitude humana em relação ao mujique e à situação em que viviam na aldeia, e nesse sentido, a literatura da época alcançou seu objetivo.

Nesse tempo, Sleptsov começou a narrar, em seu tom de calmo observador, o absurdo da vida pequeno-burguesa em Ostáchkov, uma cidadezinha que surgiu miraculosamente em torno do empreendimento do burguês Sávin, que por um lado extorquia os trabalhadores de todas as formas, e por outro decorava estranhamente a cidade com peixinhos "rufus", habilmente talhados na madeira. Esse ensaio é um verdadeiro retrato pitoresco sobre o significado histórico que o desenvolvimento da cultura estrangeira, encarnada por um predador russo, obteve em nosso país - que por um século inteiro não foi capaz de refrear uma epidemia de tifo, mas que, entretanto, conserva os melhores balés do mundo. O significado desse perspicaz ensaio de Sleptsov não pôde ser compreendido pelos jornalistas nem pela crítica literária da época. Suas mais afetuosas preocupações estavam sempre voltadas para as milhares de aldeias e as centenas de cidades russas, essas últimas em que haviam pequenas fábricas controladas por espúrios burgueses, defensores de um estúpido e fatal conservadorismo, cujas raízes penetravam profundamente nas entranhas da pétrea ignorância. Essas cidades permaneciam distantes de qualquer influência do pensamento liberal ou radical, assim como de qualquer impacto benéfico de força intelectual.

Mesmo após os acontecimentos dos anos 1880 e de 1905-6, esses ninhos provinciais russos, envoltos na inércia do tempo, não apresentaram quase nenhuma variação em suas imobilidades. O sentido sociopolítico dessas imobilidades já eram indecifráveis no tempo das "Grandes Reformas", interpretados por muitos como um período errôneo, uma maré, inundação ou uma catástrofe da natureza.

8 Tipo de peixe da família "percidae", muito comum em toda a Eurásia.

9 Período que se inicia com a ascensão do tsar Alexandre II ao trono, em 1855, e que se caracterizou por uma flexibilização das leis e da censura. O ponto alto das reformas foi a emancipação dos servos, em 1861. Após o atentado do estudante Dmitri Korokózov, em 1866, o Estado retomou sua postura conservadora, e o fim da época das Grandes Reformas não tem uma data precisa, podendo ser delimitada em 1866, 1874 ou 1881, quando do assassinato do tsar. 
Mais adiante, no ensaio "Vladímirka e Kliázma", Sleptsov narra o episódio em que os franceses trabalharam na construção de uma ponte ferroviária, e como seus engenheiros discutiam e zombavam dos trabalhadores russos; de como os trabalhadores franceses falavam aos chefes: "Eu te respeito, mas não tenho medo de ti"; e assim dizia um meninote de treze anos, que fora parar naquela região de Kliázma, vindo do Loire, sobre a Santa Rússia: "Essa é uma terra de bárbaros!"

Um russak ${ }^{10}$ conta a Sleptsov como um maquinista francês jogava água quente bem "no focinho" do supervisor da construção da ponte. Enquanto o narrador ria inofensivamente da cena com o francês, um outro russakinho afanava uns copequinhos de um estrangeiro - uma ninharia se comparada à bolada russa que os franceses levariam para casa.

Os trabalhadores franceses - descreve Sleptsov - eram homens imensos, encorpados, esperançosos; todos ostentavam barbas negras, se metiam debaixo de chapéus de pele de cordeiro e calçavam luvas bem curtidas. Alguns chefes passavam vestindo roupas revestidas em pele de guaxinim. Eles não davam ouvidos a ninguém, tampouco se importavam com os nossos - os franceses eram livres, preocupados apenas com coisas como descascar nozes e outras imperturbáveis atividades que não exigiam gritos nem aborrecimentos, fumavam seus cigarros e cantavam canções sobre a Bela França... E lá longe, debaixo da ponte, o povão desafortunado: cerca de trinta infelizes, cujas idades variavam de quinze a setenta anos, puxavam, exaustos, uma corda retorcida e entoavam uma velha canção russa:

"Negra gralhinha/ Terra limpinha/ Esposa Marussinha...

Tchernobróv, por que não dormes hoje na casinha? Irrá!"

Dez homens se equilibravam sobre o gelo e carregavam toras sobre a água congelada. Por essa razão, o serviço se dava lentamente, como se de má vontade. Cavava-se mais fundo, mais fundo, até que enfim as toras se arrastassem ou empacassem, e se arrastassem e empacassem novamente, e mais uma vez até que o encarregado observasse e gritasse:

- Ei, vocês, seus palermas! Estão vendo aquelas coisas ali, certo? Hein, palermas? Aquele aço ali? Pois bem, tragam-no até aqui!

10 Russak [Русак] é um termo antigo para "russo", normalmente atribuído para homens do interior, "caipira". 
Tudo é retratado em cores vivas, vibrantes, seguras e com mãos impressionantemente firmes; em falas breves e retratos de vidas tão hábeis, que os pitorescos métodos de trabalho para a composição do ensaio apresentam as relações entre os dois povos como se envoltas por uma nuvem densa e terrível, que se alevanta e desce, segregando para um futuro distante e absurdo, os filhos da terra russa.

Sleptsov, assim, apresentava um tema novo, nunca aprofundado antes. Ele escrevia sobre a vida dos trabalhadores das fábricas, sobre a vida mundana de São Petersburgo e temas semelhantes. Seus ensaios são cheios de premonições - talvez inconscientes - sobre os destinos de um futuro distante da Rússia; sua narrativa é carreada de elementos do senso comum, ainda impercebíveis ao seu tempo, mas que rapidamente foram incorporados por Gleb Uspiênski no livro "Os costumes da Rua Rasteriáiev" (Nrávy Rasteriáievoi Úlitsii); por Aleksándr Levítov na maravilhosa coletânea "A vida nas vielas de Moscou" (Jį̧n’ Moskóvskikh Zakoúlkov), por Mikhail Vorônov e tantos outros proeminentes escritores desconhecidos do público de hoje, mas que colaboraram em diversos números das revistas $\mathrm{O}$ Contemporâneo (Souremênnik), Anais da Pátria (Otetchêstvennie Zapiskei), A Causa (Diêlo) e A Palavra (Slóvo).

A atitude de Sleptsov em relação ao campo é o que o torna diferente dos demais escritores. Nas cenas de "O Corpo Morto" (Miórtvoe Tiêlo), nas histórias de "Os Porcos" (Sviní), "Pitómka" (Pitómka), em "O Acampamento Noturno" (Nôtchbleg), e em outras de Sleptsov, percebe-se o riso triste de um homem que desconfia de tudo o que foi dito e pensado acerca da vida camponesa. Ele retrata a ignorância do mujique, a indiferença do próximo em relação ao destino daquele que sofre todos os infortúnios e carrega, submisso, o pesado fardo da nação pela vontade de terceiros, mesmo quando torna-se evidente aos seus olhos a mesquinhez dos interesses e a exploração do seu trabalho. Esse mujique, calmamente, adentra "de penetra" na "vólost"11 e, pacientemente, espera o momento em que as autoridades o açoitarão.

O historiador da literatura russa S. A. Venguérov ${ }^{12}$ dizia que Sleptsov retratava o camponês russo como um verdadeiro "tapado"; o crítico Skabitché$\mathrm{vski}^{13}$ recriminava-o por essa atitude cética diante da aldeia russa, assim como

11 Vólost' era a mais baixa sessão administrativa do Estado Imperial Russo, atuando comumente no campo, principalmente entre os séculos XV e o final do século XVIII.

12 Semión Afanassiêvitch Venguérov (1855-1920).

13 Aleksandr Mikháilovitch Skabitchévski (1838-1911), foi um escritor e crítico literário russo, famoso por participar do movimento "Populista" dos anos 1870-1880. 
há outras opiniões de outros críticos desfavoráveis a Sleptsov. E embora todos reconhecessem a originalidade do talento do novo escritor, louvavam-no por sua simplicidade e capacidade persuasiva de suas histórias; as intrigas políticas com os grandes cânones literários de sua época, provavelmente retiraram-no dos círculos principais, isolando-o das amizades estratégicas. Essa ideia talvez explique o fato de praticamente não haver uma biografia sobre Sleptsov, exceto das memórias de Panáieva-Golovatchiôva ${ }^{14}$, amiga e colaboradora de N. A. Niekrássov. Nos anos 1860, a "Questão Feminina"15 era vista como um tema de importância social primordial, e Sleptsov foi um dos primeiros que se interessou genuinamente pelo assunto, devotando imensa energia para a causa; contribuindo, inclusive, para a abertura de caminhos para as mulheres no mundo educacional por meio da tutoria ao autoaprendizado.

Já no ano de 1863, ele iniciou uma série de palestras científicas e populares direcionadas para mulheres que vinham das províncias para São Petersburgo, em busca de conhecimento e liberdade, o que era naturalmente de praxe num país onde a maioria esmagadora era iletrada. Esse movimento pró-mulheres foi duramente criticado pelos maliciosos conservadores, que alardeavam o fim da família e sobre os perigos que poderia causar à nação. Esses deram às mulheres, a cáustica alcunha de "horizontais", atribuindo-lhes toda espécie de pecados e vícios.

Mas as palestras de Sleptsov foram frequentadas por mulheres da estirpe de Nadiêjda P. Súslova, filha de um camponês que foi a primeira mulher russa a receber um título de doutora em Ciências Médicas, na Suíça, e que atuou e escreveu diversos artigos em São Peterburgo e Níjni Novgorod. Ou Maria Bókova, que também conseguiu o título de doutora, só que na Alemanha, e que se tornou famosa em Londres como cirurgiã em doenças oftalmológicas. Sleptsov também era familiarizado com Sofia Kovaliêvskaia, proeminente professora de matemática na Universidade de Estocolmo.

Entretanto essas palestras não foram bem-sucedidas: a escolha dos palestrantes não agradou muito o público, o número de mulheres que realmente queriam aprender era menor do que as que iam apenas para saber as novidades, e como

14 Eles se referem às "Memórias" de Avdótia Panáieva-Golovatchiôva, publicadas em 1889.

15 A “Questão Feminina” (Jênskii Voprós) debruçava-se, basicamente, neste período, sobre três grandes temas: o direito à liberdade matrimonial (escolher o cônjuge, pelo menos), o direito a uma educação que fosse minimamente equiparada à dos homens, e o reconhecimento profissional. 
se pode presumir nesses casos, a fofoca tomou lugar da ocupação séria. Mas isso não desencorajou Sleptsov, que logo criou uma "comuna" - um apartamento para interessadas em ciências, onde também se organizou uma cooperativa de costureiras, abriu um escritório para a formulação de documentos, organizou traduções de textos de línguas estrangeiras, palestras públicas e debates literários para suas "comunistas". Em suma, trabalhou com obstinada resiliência para fazer o que estava ao alcance do seu tempo e das condições oferecidas pela sociedade russa. Essas atividades intensificaram a cruel perseguição às frequentadoras da comuna, e culminou com uma batida policial. Os cidadãos logo espalharam boatos de que Sleptsov criara uma espécie de seita, algo com uma galé de forçadas, e que nessa seita reinava uma intensa promiscuidade; então, a polícia, suspeitando algo mais, conduziu Sleptsov até os porões do Monastério de Aleksándr Niévski, onde ficou por sete semanas e lá adoeceu de modo irremediável.

A sede incontrolável de vida e sua participação ativa na mesma, indubitavelmente prejudicaram uma atividade mais assídua como escritor. E Sleptsov escreveu mesmo pouco, ocupando seu tempo e energia em viagens pelos confins da Rússia, na Questão Feminina e na vida, de modo geral.

O maior e mais maduro trabalho de Sleptsov foi o romance "Tempos Difíceis”, que retrata perfeitamente um dos incontáveis dramas da época, mesmo que esse drama, por vezes, se transmute em comédia - o que é uma característica típica do drama russo, em que sempre temos infindáveis narrativas tediosas e muito pouca paixão original. Schettínin, sua esposa e Riazánov são típicos heróis de um tempo difícil. Sleptsov descreve-os com maestria, como um verdadeiro artista. A esposa de Schettínin é uma daquelas mulheres que, levadas pelas agitações da época, romperam com os difíceis laços familiares russos para seguirem ou perecerem à chama do conhecimento em cidades como São Petersburgo, na distante Suíça, nas "idas ao povo" ou nas prisões, exílios e trabalhos forçados do sistema penal russo. Maria Schettína talvez fosse uma das mulheres que assistiram às palestras de Sleptsov, que moraram em sua "comuna" ou tenha morrido na luta pela liberdade de seu país.

Riazánov, por sua vez, é um daqueles intelliguenti que, percebendo que seus ideais são estranhos e incompreensíveis ao povo e às outras classes todas, adquirem um tom hostil e uma atitude crítica diante dos "sacramentos" da vida russa. Abraçando o espírito da negação e da rejeição orgulham-se de sua condição de niilistas. Por natureza, Riazánov é um irmão literário do niilista Bazárov, do romance "Pais e Filhos", de Ivan Turguêniev, mas ele tem uma conduta mais natural e mais próxima da vida real do que o herói de Turguêniev. 
“- Isso não é a vida, - Ele diz a Maria Schettína. - mas só o diabo é quem sabe como funciona essa porcaria toda... Há sempre um ponto de vista em que é possível observar todo o desengano da vida de modo simples e cristalino. Mas as pessoas, como que de propósito, escolhem enxergar só o dedo mindinho do capeta, porque parece ser mais divertido, surpreendente e aterrorizante. Bem, assim o tempo vai passando, como você mesma tem vivenciado.

- Mas e então? - Perguntou Schettína. - Como fica a vida de uma pessoa que perdeu a chance de viver tal qual os outros vivem?

- Como fica? - Riazánov olhou em volta de si. - Fica precisando ser reinventada, mas até lá, então...

Ele fez um movimento de desistência com a mão."

Essa é uma imagem do desengano que perturbava as cabeças e os espíritos das pessoas de senso crítico na época dos "tempos difíceis", uma gente que não tinha um lar para chamar de seu. Os Bazárovs e Riazánovs foram criados pela vida russa como que por um ato irrestrito de condenação. Seus papéis na trama são desinteressantes, uma vez que seus corações e mentes já se entregaram à negação, mas são como tantos outros heróis que deram a vida pela causa revolucionária, cujos nomes ficaram respeitavelmente inscritos nas histórias da luta pela liberdade e pela cultura.

\section{О Васимии Смепцове}

Крупный, оригинальный талант Слепцова некоторыми чертами сроден чудесному таланту А.П.Чехова; хотя Слепцов совершенно не владел вАумчивой, грустной Аирикой, чутьём природы и мягким, однако точным языком Антона Чехова, но острота наблюдений, независимость мысли и скептическое отношение к русской Аействительности очень сближают этих писателей, Аалёких Аруг Аругу в общем.

Очерки Слепцова появились в те годы, когда в русской митературе особенно громко начали раздаваться голоса “кающихся дворян”, зазвучала чувствительная исповедь потомков о грехах предков, - исповедь весьма многослойная, не всегда серАечная и еАва Аи уместная, ибо то, что называлось “грехом предков” (“отцы ели кислый винограА, а у детей на зубах оскомина”, Иеремия, 31, 29), было исторической неизбежностью, обязательным Аля всех народов этапом культурного развития и требовало не словесного раскаяния 
потомков, а их упорной борьбы с окаменелостями прошлого в мыс ии и Аеле, в быте и чувстве. ТогАа разыгрывалось в русской митературе и пол её влиянием в обществе второе действие странной романтической Арамы, героями которой явАялись, с оАной стороны, вАюблённая интелАигенция, с Аругой — бесчувственный народ, причём за подлинный народ принималось только большинство населения — крестьянство, Аругие же классы, например, рабочий, как бы не существовали и не замечались митературой. О народе ^итература говорила, как и наАлежит вАюблённой, повышенным тоном, стараясь подчеркнуть прежле всего положительные начала его психики и быта, невольно преувеличивая их, но в общем стремясь пробудить гуманное отношение к мужику, действительное внимание к Аеревне, что и было Аостигнуто Аитературой.

В это время Слепцов заговориц тоном спокойного наблюдателя о нелепой жизни мещанского городка Осташкова, — городка, который чудесным каким-то образом весь приналиежит купцу Савину, а купец, всесторонне грабя его, в то же время односторонне украшает ершами, весьма искусно вырезанными из дерева. Смыс $э$ этой исторически верной картинки развития внешней культуры, творимой русским хищником, который в течение столетия не мог избавить страну от ежегодных эпидемий тифа, но создац мучший в мире балет, - смысл этого умного очерка остался не понят публицистами и журналистами эпохи. Их сердечное внимание было направлено в сторону тысяч деревень, а сотни уездных городов русских — эти фабрики очень мелкой и скудоумной буржуазии, тупого, мёртвого консерватизма, устои коего ушли глубоко в недра каменного невежества, -

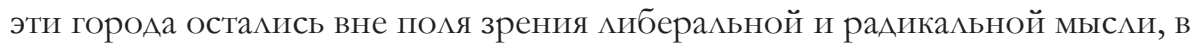
стороне от благотворного влияния интемлектуацьной симы.

После — в восьмилесятых, в 1905-6 годах — уездные гнёзаа российской косности очень тяжко показали устойчивость своего быта, социаАьно-политическое значение этой устойчивости остается неАостаточно понятым и в Ани “великих реформ”, принятых многими подобно трусу, мору, потопу и вообще “стихийным катастрофам”.

Аалее, в очерке "ВАадимирка и КАязьма" Слепцов рассказывает, как французы строят железнодорожный мост, как они ссорятся со своими инженерами и немножко издеваются наА русскими; как рабочийфранцуз говорит начальнику своему: “Я вас уважаю, но — не боюсь”, а тринаццатилетний мальчуган, попав на суздальскую КАязьму с французской Ауары, говорит о Святой Руси: “Это край варваров”. 
Русак рассказывает Слепцову, как машинист-француз пускает “в рыло” главного приказчика строителей моста струю горячего пара, рассказчик безобидно смеётся наА шуткой француза, а в это время Аругой русачок выманивает у иноземца несколько медных копеек - нищенскую сдачу с тех пудов русского золота, которые французы увезут на свою родину.

Работают французы, - описывает Слепцов, - народ всё крупный, такой основательный, надёжный, все с такими густыми, чёрными бородами, в тёплых мерлушковых шапках, в Ауб̆ёных рукавицах. Прошёл какой-то начальник в енотовой шубе, - никто и ухом не повёл, никому Ао него и Аела нет, всякий занят своим, прицаживают гайки, и всё это так просто, свободно, без криков и понуканий, покуривая сигарку, распевая песенки о своей прекрасной Франции... А там, внизу, под мостом, копошится народ: человек тридцать каких-то нищих всех возрастов, начиная с пятнадцати и Ао семилесяти Ает, усиленно Аёргали измочаленный канат и тянули песню прекрасной России:

Черная галка,

Чистая полянка,

Жена Марусенька,

Черноброва -

Чего не ночуешь дома?

$-\mathrm{Y}_{\mathrm{X}}$ !

Человек Аесять ковырялись во Аьду, таская из воды обмёрзлые брёвна. И так-то вяло, как будто нехотя. Поковыряют, поковыряют Аа почешутся или примутся зевать и потягиваться и до той поры зевают, потягиваются, пока не увиАит их Аесятник и не закричит:

- Эй, вы! Шмони вы эдакие, право — шмони. Ну, что стали? Эх, палки на вас нет!

Всё это нарисовано очень живо, Аовкой, твёрдой рукой и настолько внушительно, что из краткого, спешного очерка приёмов работы, навыков жизни, отношений Авух племён как будто возникает некая жуткая и густая тень, возникает и падает Аалеко вперёА на будущее нелепой русской земли.

Слепцов вообще брал темы новые, не тронутые до него; он писал о фабричных рабочих, об уличной жизни Петербурга; его очерки полны намёков — вероятно, бессознательных — на судьбу отАалённого будущего страны, полны живого смысла, не уловленного в своё время, но его темы тотчас были подхвачены ГАебом Успенским в книге “Нравы Растеряевой 
улицы”, Аевитовым и Вороновым в их славной книжке “Жизнь московских закоулков” и затем целой группой менее вилных, забытых теперь писателей, сотрудников “Современника”, “Отечественных записок”, “Аела” и “Слова”.

Отношение Слепцова к Аеревне заметно разнилось с общим повышенным отношением к ней. В сценах "Мёртвое тело”, в рассказах “Свиньи”, "Питомка”, “Ночлег” и прочих у Слепцова чувствуется печацьная усмешка человека, который сомневается во всём, что в ту пору было принято Аумать и говорить о деревне. Он изображает мужика неумным, равнодушным к ближнему и своей судьбе, притерпевшимся ко всем несчастьям, почти безропотно подчинённым чужой воле Ааже тогАа, когАа ему ясно, что её цели и глупы и вредны его интересам. Этот мужик спокойно ходит в волость “пороться" и терпеливо жАёт, когда начальство удосужится выпороть его.

Историк русской митературы С.А.Венгеров говорит, что Слепцов изображал мужика “настоящим головотяпом”; критик Скабичевский упрекац его в поверхностно скептическом отношении к Аеревне, есть и ещё мнения, не местные Аля Слепцова. И хотя все признавали оригинальность таланта нового писате я, хвалили его за простоту и убедите ьность рассказов, однако

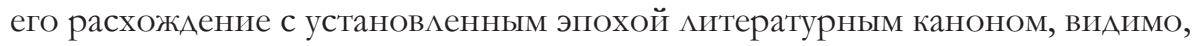
отодвигало его в сторону от митературных кружков, остав яяя человеком без Арузей. Аумать так позволяет то обстоятельство, что о С епцове почти нет воспоминаний, кроме рассказа о нём Панаевой-Головачёвой, подруги и сотрудницы Н.А.Некрасова. В шестилесятых годах “женский вопрос" рассматривался как вопрос первостепенной социальной важности, Слепцов был одним из первых, кто искренне увлёкся вопросом и посвятил ему не мало энергии, всячески пытаясь облегчить женщинам путь к знанию и самообразованию.

Уже в 1863 году он затевает рял популярно-научных мекций Аля женщин, которые в то время Аесятками съезжацись из провинции в Петербург, стремясь к знанию и свободе, что было законно и естественно в стране мацограмотной. Это Авижение решительно и злобно порицалось консерваторами, они кричали о разрушении семьи и опасностях, вытекающих отсюда Аля нации, они Аали учащимся женщинам едкое прозвище “горизонталок”, приписывая им все грехи и пороки.

Но мекции Слепцова посещались такими женщинами, как Н.П.Суслова, Аочь крестьянина, первая русская женщина, получившая в Швейцарии звание доктора медицинских наук и потом практиковавшая в Петербурге, в Н.-Новгороде, автор нескольких ценных сочинений по 
медицине; Бокова, которая тоже впоследствии получица дип оом доктора в Германии и стала известным в знакома со Слепцовым и Софья Ковацевская, знаменитая как профессор математики в Стокгольме.

Но эти мекции не имели успеха, - подбор мекторов оказался недостаточно удачным, женщин, которые искренне желали учиться, было меньше, чем тех, которые мнимо желали этого, и, наконец, как это само собой разумеется, вокруг честного дела неизбежно возникли грязные сплетни. Это не обескуражило Слепцова, он устроил нечто вроде “коммун” — общую квартиру Аля тружениц науки, пытался устроить А^я них переплётную и белошвейные мастерские, открыть контору Аля переписки Аеловых бумаг, организовац переводы с иностранных языков, устраивац публичные мекции, спектакли, митературные номера в пользу своих “коммунисток”, делал всё, что позволяли условия времени и стойкое сопротивление русского быта; эти его затеи ещё более усилили грязные сплетни и, наконец, привлекли внимание полиции. Обыватели стали говорить, что Слепцов основац новую секту, нечто вроде “корабля” хлыстов, что в секте царит дикая распущенность, и полиция, подозревая нечто иное, арестовала Слепцова и посаАила его в “каталажку” А^ександро-Невской части, откуда он через семь недель вышел больным.

ЖажАа непосредственной близости к жизни, деятельное участие в ней, несомненно, мешали кропотливому труду писателя, и Слепцов писал немного, тратя силы и время на путешествия пешком по Аорогам российским, на “женский вопрос" и вообще — на жизнь.

Самое крупное и наиболее зрелое произведение Слепцова - повесть “Трудное время" - превосходно изображает одну из бесчисленных драм эпохи, и хотя порою эта Арама переходит в комеАию, но это вполне типично Аля русских Арам, в которых всегда слишком много нудной словесности и так мало подиинной страсти. Щетинин, его жена, Рязанов — типичные

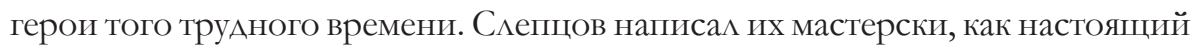
художник. Жена Щетинина — это одна из тех женщин, которые, увлекаемые тревогой эпохи, смело рвали тяжкие узы русского семейного быта и, яв яясь в Петербург, или погибали в нём, или ехали за огнём знания дальше — в Швейцарию, или же шли “в народ”, а потом — в ссылку, в тюрьмы, в

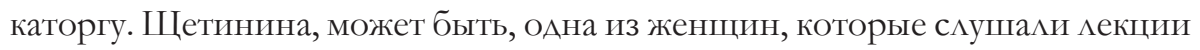
Слепцова, жили в его “коммуне” и, несомненно, погибли в борьбе за свободу своей страны. 
А Рязанов - один из тех интеллигентов, которые, сознавая, что они непонятны, не нужны и чужды “народу”, а всем другим классам враждебно их критическое отношение к “устоям” русской жизни, отАаваАи себя Ауху “отрицанья и сомненья” и с гордостью приняли кАичку нигилистов. По натуре своей Рязанов - родной брат нигилисту Базарову из книги Тургенева “Отцы и Аети”, но он — человек более естественный и мучше знающий жизнь, чем знал её герой Тургенева.

— Это и не жизнь, — говорит он Марии Щетининой, — а чорт знает что, Аребедень такая же, как и всё прочее... Есть такая точка зрения, с которой самое Аюбопытное Аело кажется столь простым и ясным, что на него скучно смотреть... Но обыкновенно Аюди, как нарочно, выбирают такие Аела, в которых чорт ногу переломит, потому что хотя толку от этого бывает мало, зато на каждом шагу можно удив яться, радоваться и ужасаться. Ну, время-то и проходит, и кажется, что как будто в самом деле живёшь.

- Но что же тогда? - спрашивает Щетинина. - Что же остается Аелать человеку, который потерял возможность жить так, как все живут?..

- Остаётся, - Рязанов посмотрел кругом, - остается вылумать, создать новую жизнь, а Ао тех пор...

Он махнул рукой.

Это очень безнадёжно, но такие мысли и настроения должны были мучить наиболее наблюдательных мюдей “трудного времени”, — людей, которым “некуда" илти. Базаровы и Рязановы созданы русской жизнью как бы нарочито Аля безудержного осужАения ею же самой себя. Эту роль они исполнили самоотверженно, разбив себе отрицании, но по трупам их в жизнь вошли Аюди революционного Аела, сотни героев, имена которых почтительно вписаны на страницы истории борьбы за свободу и культуру.

\section{Referências}

BRUMFIELD, William C. Bazarov and Rjazanov: The Romantic Archetype in Russian Nibilism. The Slavic and East European Journal, Vol. 21, n. 4 (Winter, 1977), pp. 495-505. . Sleptsov Redivivus. Ad Litteram, 2014, n. 2. pp. 357-389.

. Two Hamlets: Questioning Romanticism in Turgenev's Bazarov and Sleptsov's Riazanov. Journal of Siberian Federal University. Humanities and Social Sciences, 2015. 
IAKÚCHIN, N. Krúpnii, Origuinálnii Talánt. 1970. Disponível em: < $\underline{\text { http://az.lib.ru/s/ }}$ slepcow w a/text 0050.shtml>

ROGACHEVSKII, Andrei. Precursors of Socialist Realism: Vasilii Sleptsov's "Trudnoe Vremia" and its Anti-Nibiist Opponents. The Slavonic and East European Review, Vol. 75, n. 1 Jan., 1997), pp. 36-62.

TCHUKÓVSKI, K. I. Literatúrnaia sudbá Vassília Sleptsova. Literatúrnoe Nasledstvo. Vassili Sleptsov. Moskva: Izdatel'stvo Akademii Naúk SSSR, 1963.

THORSTENSSON, Victoria. The Dialog with Nibilism in Russian Novels of the 1860s-1870s. A dissertation submitted in partial fulfillment of the requirements for the degree of Doctor of Philosophy (Slavic Languages and Literatures) at the University of WisconsinMadison, 2013. 